\title{
Evaluation and Action: Sustaining Excellence in Collegiate Aviation Distance Education
}

\author{
Nanette M. Scarpellini and Brent D. Bowen \\ University of Nebraska at Omaha
}

\begin{abstract}
This study assesses the role of the evaluation process in sustaining and developing quality distance education programs in collegiate aviation. Distance education encompasses distance learning and distributive learning as well as e-learning and multiple method crossover delivery that includes some form of electronic delivery. The research explores the sanctioned position of evaluation procedures and their practical application in the outcomes assessment process within collegiate aviation distance education programs as compared to traditional delivery methods. Additionally, the study investigates the criteria for determining outcomes assessment based on establishing methods for interpolating contact hours, applied testing, and gauging learning. The methodological approach includes a literature review and a survey instrument implemented by semi-structured phone interviews. The gathered data are based on a review of accredited graduate and undergraduate collegiate aviation distance programs. The findings demonstrate that evaluation is an underutilized method for sustaining and ensuring a high-level academic product is delivered via distance education. The lack of consistent terminology for classifying and measuring distance education, and more specifically, the meaning of quality, further complicate this. Further research is recommended in order to reach a consensus on defining vocabulary of distance education elements and the role and application of evaluation. Additionally, the recommendations provide guidance in modifying the curriculum for achieving consistent results commensurate with accreditation standards.
\end{abstract}

\section{INTRODUCTION}

The evaluation process continues to be an integral part of sustaining and developing quality distance education programs in collegiate aviation. As technology turns education into a global event, the learning process is less restricted to a traditional classroom setting. For the purpose of this study, distance education consisted of distance learning and/or distributive learning that occurred through any form of e-learning or multiple method crossover delivery, which included any type of electronic delivery. This encompasses online teaching and learning, as well as academic support and student support services that were fully or partially electronically delivered (Eaton, 2000).

Students and teachers communicate and learn via distance education programs cropping up across the United States and the world at an ever increasing rate. While the opportunity to learn was at an all-time high, the possibility of failure was just as great. Aviation programs were selected for this study due to their limited number and the congruency of their programs. The basis for this study came from prior surveys conducted to discover in the collegiate aviation community which schools were involved in distance education (Bowen, 
Freeman, Scarpellini \& Schaffart, 2000). This study explored the sanctioned position of evaluation procedures and their practical application in the outcomes assessment process within collegiate aviation distance education programs as compared to traditional delivery methods. Additionally, the study investigated the criteria for determining outcomes assessment based on establishing methods for interpolating contact hours, applied testing, and gauging learning.

This study was based on the assumption that the same standards for oncampus courses applied to distance education courses since the U.S. Department of Education notes no need for different standards (U.S. DE, 1999). Furthermore, the relative newness and unfamiliarity of distance education limited the amount of established program maintenance evaluation. Distance education providers lacked a consistent vocabulary to be able to organize and compare different aspects of the program from one school to the next (Wolf \& Johnstone, 1999). The lack of vocabulary uniformity restricted the classification and measurement of distance education, especially in the area of quality definition.

The primary goal of this study is to determine which schools are involved in delivering collegiate aviation distance education or who are planning to do so in the near future. By determining the appropriate respondents, the research examined the role of evaluation in ensuring quality delivery and outcomes-based assessment in collegiate aviation. The respondents contributed information through a semi-structured phone interview that allowed for snowballing to determine other applicable participants. The questionnaire established the status of program evaluation at each location.

The methodological approach highlighted the survey method that was supported by an extensive literature review. This combination enabled valid and reliable data collection (Wiggins \& Stevens, 1999). A literature review within the Contextual Knowledge Framework section of this research examined recently published material relating to evaluation and accreditation of distance education programs as well as benchmarks in this method of delivery. Information from the World Wide Web was used in comparison with related dissertations and scholarly articles. Searches were conducted using key words as well as exploring the links provided by the websites of leaders in distance learning within the educational and industry areas. The review findings also explored how other disciplines dealt with the same concern. This broad overview of standards and accreditation measures narrowed the focus to the progress and development of evaluation procedures in collegiate aviation distance education.

Distance education is a relatively new form of learning delivery. The research findings of this study support recommendations that may enhance effective delivery and distance education outcomes overall. As more institutions become involved with providing degree programs through electronic delivery, the problem of inadequate follow-up evaluation will widen if not addressed now. While the accreditation process attended to evaluation for accreditation purposes, the distance education administrators needed to adopt a proactive stance in order to ensure evaluation continued to focus on the needs of their students and faculty. Recommendations for regular evaluation and assessment by both the student and the instructor were supported by the research (Eaton, 2000). By supporting greater focus on continuity of communication throughout the program, curriculum may need to be modified. These changes, while still 
commensurate with accreditation standards, will improve the outcomes consistency.

\section{DISCUSSION}

\section{Contextual Knowledge Framework}

Distance education sparked a deluge of literature (Eaton, 2001b; Bowen, Scarpellini, Fink \& Freeman, 2001). The articles extolling the virtues and vices of distance learning confuse the subject when trying to sort between educational opportunities and moneymaking schemes. An extensive search of web resources covering accreditation and evaluation of distance education programs, coupled with a review of dissertations and scholarly articles, formed the crux of this study. The primary source of standards and expectations was the Council for Higher Education Accreditation (CHEA), the national coordinating body for national, regional, and specialized accreditation. According to Judith Eaton, current CHEA president, the organization offered its own recommendations as well as guidance to researchers and educators alike. The organization tracked enrollments, new providers, faculty role, and quality review to examine how accreditors and external reviewers assure quality in distance education (Eaton, 2000). Additionally, The Western Cooperative Education Telecommunications' (WCET) Principles of Good Practice for Electronically Offered Academic Degree and Certificate Programs formed the foundation for the distance learning practices applied by the eight regional accrediting commissions (Eaton, 2000).

Distance education appears to have brought new challenges to the accreditation process. Recent CHEA findings determined that traditional accreditation procedures might not be as appropriate for ascertaining the quality of distance learning. CHEA proposed the emergence of competencybased review focused on student outcomes (Eaton, 2001b). According to Eaton, student outcomes referred to ". . . what students learn, what students achieve, and how they perform, whether full-time or part-time, degree-bound or engaged in ongoing education" (p.1). While traditional core academic values remained at the center of distance education, different measures worked more effectively in assessing quality learning.

The outcomes-based standard has been presented as a measure that minimizes the limitations of distance learning. Due to its flexibility, this standard can be more open to external quality review through accreditation and may present a more accurate picture of the learning experience (Eaton, 2001b). In 1998, CHEA and the National Center for Higher Education Management Systems (NCHEMS) initiated and tested an unconventional accreditation standards and review method. They worked in conjunction with Western Governors University (WGU) who ultimately directed the Competency Standards Project program. This alternative approach differed in four principal areas with the customary institutional review. These areas include concentrating principally on teaching and learning, greater dependence on existing teaching and learning information, stressing outcomes over capacity and processes, and providing team decision-making added structure (Eaton, 2001b). The Competency Standards Project found a distinct and recognizable correlation between institutional quality to student achievement. A key step ". . . is to develop the standards that address consequences-outcomes, results, competencies - in physical space or cyberspace" (Eaton, 2001a, p. 8).

As distance education slowly established standards, it must work doubly hard to maintain them. According to 
Carnevale (2001), the American Federation of Teachers requested that colleges not only acknowledged, but also assumed the standards and collective-bargaining agreements to protect the quality of distance education. This included not only content and technical support standards, but faculty training for online teaching as well (American Federation, 2000). These AFT programs addressed all aspects of the learning process to maintain and attract a receptive student body. In a survey of students enrolled in a distance education program conducted at the University of Nebraska at Omaha, Krzycki (1998) found student satisfaction was directly linked to the student-faculty interaction. This exchange ranked higher than any other aspect of the program.

The teacher-student relationship must be established early and maintained through timely feedback. According to Eaton (2000), all too often instructors were thrust online without the proper training or time to manage this new and important connection. Distance education presented a challenge for teachers, as they were faced with a new kind of delivery system. Regular evaluation by the student and instructor allowed effective monitoring so instructors were able to correct their situation as needed. Different delivery techniques were necessary to facilitate learning in distance education (Burnham, 1994). In a study of graduate students by Scott-Fredericks (1997), the online experience required students to pass through stages of understanding to become skilled learners in computer-mediated communication. The progression involved causal and intervening conditions that included ". . . the need for direction, support, and level of dependence on the instructor" (p.1). As a result, the instructor played a key role in the students' mastery of the learning process.

The demand for access to higher education has steadily increased in recent decades due to changes in the economic and social structure (Bowen, et al, 2001). Rapid advances in technology have fueled the growth as it widens education's accessibility. With the number of people seeking higher education rising, key issues concerning information technology have been identified as content, delivery, and infrastructure (Green, 1999). This included not only the extent of the topic matter delivered, but also the different types of delivery used, including discussion boards and on-line lectures. All of these elements combined within a predetermined framework to ease in standardization and continuity. Technology made education accessible; it does not produce learning without the appropriate inputs and outputs by both the instructor and the student.

In a review of distance education research, Merisotis and Phipps (1999) reported that the majority of findings detected little difference in learning outcomes for students participating through distance education as opposed to the traditional classroom. They studied research investigating student outcomes, student attitudes, and overall student satisfaction. However, their analysis was limited by the lack of reliable research covering the topic, particularly when considering the possible exclusion of dropouts from distance learning studies. Distance education required skill sets beyond the reach of many distance learners. While technology opened the door of education to countless people, it could not eliminate the human factor without significant loss of quality (Merisotis \& Phipps, 1999). Essentially people still need the interaction and exchange between other people in order to fully learn and grow. If all learning could be done straight from books, traditional classrooms would have closed long ago. Technology facilitated the learning delivery; it did not replace the need for 
active faculty involvement in ensuring that learning and understanding occur.

Establishing a consistent vocabulary to refer to distance education and its components would help in building a strong foundation for evaluation and comparison. The current confusion surrounding terminology caused problems for potential students, professional educators, and the general public (Wolf \& Johnstone, 1999). While it was not necessary to label every aspect of distance education, Wolf and Johnstone suggested a set of frameworks that aligned as closely as possible with traditional higher education usage. Areas to consider included institutional taxonomy and frameworks for electronic course configurations.

Performance indicators need to be connected to decisions relating to program development, enrollment management, and/or allocation of resources. The U.S. News \& World Report standing system provides useful indicators because they are widely accepted for ranking graduate schools in terms of market choice. The findings correlate highly with the rating conducted by the National Academy of Sciences (O’Neal, Bensimon, Diamond \& Moore, 1999).

The American Federation of Teachers (AFT) took an active role in distance education. After issuing its first report in 1996, the organization released regular follow-up reports dealing with a variety of distance education issues ranging from workload to cost, and to educational quality. Last year, the AFT produced Distance Education: Guidelines for Good Practice that compiled the findings from a survey of 200 practitioners of distance education in post-secondary institutions (AFT, 2000). The study's focus was on collegiate distance education in creditbearing degree courses at either of the following levels: graduate, four-year, or two-year. While the study may have been limited to these groups, the results had a broader applicability to other forms of distance education.

The AFT guidelines touched on key areas of education delivery. As opposed to using broad generalizations, the paper attempted to provide specific action steps to promote a high level of interchange between educators and students. The AFT program was broken down into 14 inter-connected steps that detailed the teacher-student distance education experience. Foremost was the affirmation that faculty must retain academic control. Keeping teaching and research faculty involved in the curriculum development superseded the use of curriculum specialists. To this end, the faculty needed to be " . . .appointed and evaluated through traditional processes involving the faculty and the department" (AFT, 2000, p.7). Evaluation continued to be a prominent feature throughout the guidelines as they touched on special requirements of teaching at a distance, which were course design potentials, student understanding, personal interaction, and subject, student and coursework assessment. Additionally, by proposing the creation of a national information clearinghouse and a program of targeted research, the AFT (2000) recommended federal government involvement in the evaluation of distance education. The high standards associated with these developments were established and evaluated by regional and specialized accreditation agencies. The level of achievement should be the same for students whether they were taught in a traditional classroom or electronically (WICHE, 1999). Accreditation Boards for Various Professions

In a review of the websites for a range of professional accreditation boards, distance education was given only minor attention. The Accreditation Board for Engineering and Technology, Inc. (ABET) 
certifies programs related to engineering and technology. Currently, they do not differentiate between traditional and distance delivery methods or assessments. A large portion of the programs ABET evaluated required onsite laboratory practice that is ill-suited to distance techniques. When possible, distance delivery was worked into various components of more applicable programs. Likewise, the American Psychological Association (APA) has been slow to address the potential of employing distance education techniques. The accreditation standards created in 1996 did not reflect an inclination to acknowledge or pursue evaluation of this area. Most accreditation boards were more amenable to exploring the potential of distance education than ABET and APA.

The National Association of Schools of Public Affairs and Administration (NASPAA) took a proactive stance on distance education, as reflected in its website. In 1995 and 1996, NASPAA conducted surveys concerning the development and implementation of related distance education programs. The second survey noted an increase in distance education programs in the course of one year up to $38 \%$ indicating they offered distance education programs (NASPAA, 1998). Additionally, the students, faculty and institutions involved with the distance education programs reported an overall positive effect as a result of the interaction.

\section{Collegiate Aviation Programs}

The Council on Aviation Accreditation (CAA) in July 1997 organized an Ad hoc Committee on Distance Education to study distance education accreditation issues (Bowen, et al, 2000). The committee compiled information relevant to aviation distance education accreditation. The Ad hoc Committee on Distance Education conceded, “...it is evident that a struggle exists to define this rapidly changing issue. An emerging common thread is the conveyance that standards are not exempted for curricula delivered via technology. However, interpretation of standards to accommodate unique and innovative systems for distributed learning is necessary" (Ad hoc, 1998, p. 1). In response to the needs of the committee, a survey was constructed to explore the nationwide issues and implications of distance education and distributive learning among aviation professionals (Bowen, et al, 2000). The survey found that "Distance education is becoming an increasingly significant issue in aviation education, as its role is expanding in education as a whole" (p.23). By instituting standards now, it would be easier to ensure the quality of distance programs as they continue to develop.

The significance of measuring student responses was also recognized as an important aspect of the distance education evaluation process (Bowen, et al, 1999). In this study, the Teaching Analysis By Students (TABS) evaluation was administered to students enrolled in computer-mediated aviation courses at the University of Nebraska at Omaha (Bowen, et al, 1999). Additionally, the instructor, who was the same for both computermediated aviation courses, completed a selfevaluation. The study found student evaluations, when used in combination with the instructors' self-evaluation, supplied important data in terms of the educational experience. The data could be acutely insightful in terms of distance education effectiveness measurement when gathered midterm and near the completion of a course. TABS data, in conjunction with additional contextual research collected on and by the instructor, identified particular teaching strengths, isolated teaching problems, and developed improvement 
strategies to combat these problems (University of Massachusetts School of Education, 1974-1975). Distance education was more successful when developed in combination with a system of evaluation that provided midterm feedback (Bowen, Scarpellini \& Vlaseck, 1999). Researchers found that as student satisfaction intensified, the attrition rates decreased and achievement rose.

\section{Regional Accrediting Bodies}

The Commission of Secondary Schools (CSS), comprising six regional accrediting bodies, presented a nearly unified view of distance education program accreditation. Of the six regional accrediting bodies, only the Middle States Association of Schools and Colleges failed to address the role of distance education as an aspect in the accreditation process in its accreditation literature on its website (CSS, 2001). The other accrediting bodies encompassed by CSS included the New England Association of Schools and Colleges, the North Central Association Commission of Schools, the Northwest Association of Schools and Colleges, the Southern Association of Colleges and Schools, and the Western Association of Schools and Colleges. This commission managed the accreditation process for accrediting college and university degree programs.

While the Middle States Association of Schools and Colleges offered no opinion on distance education, the New England Association of Schools and Colleges (NEAS\&C) recently adapted its process to include the accreditation of academic degree and certificate programs offered through distance education. NEAS\&C policy acted in conjunction with its standards for accreditation (NEAS\&C, 1998). NEAS\&C "...endeavors to enhance the quality of teaching. It encourages experimentation with methods to improve instruction"
(Commission on Secondary Schools, 1998, p. 9).

The Northwest Association of Colleges and Schools (NACS) integrated distance learning within its standards for continuing education and special learning activities. The 1996 Accreditation Handbook, produced by the Commission of Colleges of the NACS, offered basic provisions for the distance education methods. Distance education held a minor role with little influence on the total accreditation process.

The Southern Association of Colleges and Schools (SACS) proffered distance education a more detailed position within its accreditation standards than most of the other regional accrediting groups. In the Criteria for Accreditation, composed by the Commission on Colleges in 1998, several sections addressed the role of distance education in delivering learning opportunities.

The North Central Association (NCA) volunteered no definite statement regarding the accreditation position for distance education programs. The general guidelines of the Criteria for Accreditation did not specifically mention or contain distance education, but "...their generality ensures that accreditation decisions focus on the particulars of each institution's own purposes, rather than on trying to make institutions fit into a pre-established mold" (North Central Association, 1998, p. 2). When assessing accreditation for distance education program quality, NCA evaluated every program on an individual basis.

The Western Association of Schools and Colleges (WASC) led the way in addressing accreditation of distance education. The WASC continues to cultivate the process. In a Policy Statement on Distributive Learning and TechnologyMediated Instruction, "WASC intends for its role in assuring institutional quality to be 
supportive of innovation and creativity. Distance education and technologymediated instruction have already generated considerable creative approaches to teaching and learning" (Western Association, 1998, p. 1). To ensure the public of distance education program's quality standards, WASC asserted ". . . the accreditation process will continue to focus on the overall quality of an institution. Although there are many similar issues, distance education does raise quality issues that are distinctive from those relevant to on-campus programs" ( $\mathrm{p}$. $1)$.

Federal Government Assessment and Programs

The U.S. Department of Education's (U.S.DE) accreditation guidelines treated distance education as a method of delivery, not an independent program. For that reason, "...we [U.S.DE] will observe and evaluate, as part of our regular review of an agency for initial or continued recognition, the agency's compliance with the criteria for recognition, including the agency's compliance in accrediting distance education programs and institutions" (U.S.DE, 1999, p. 56614). Regulations did not vary for distance education.

Under Title IV of the Higher Education Amendment of 1998, two programs were created to increase the scope of students served by distance education. First, the Distance Education Demonstration Program waived distinct statutory and regulatory requirements for student aid in relation to distance education, thus modifying financial aid distribution parameters (University of Continuing Education Association, 1999). Additionally, Congress appropriated $\$ 10$ million for the Learning Anytime Anywhere Partnership (LAAP). The LAAP offered "... competitive grants to increase student access to highquality, technology-mediated learning opportunities that are not limited by the constraints of time and place" (Lekander, 1999, p. 1). The Fund for the Improvement of Post-secondary Education (FIPSE) controlled the program. Technologymediated distance learning was recognized as a significant resource enhancing the lifelong learning on a national level.

\section{METHODOLOGICAL APPROACH PROCESS}

\section{Research Questions}

To determine the status of the evaluation process in collegiate aviation distance education, a thorough literature review was performed. Based on the information from this framework of knowledge, a survey instrument was constructed that further addressed the research hypotheses posed by this study.

This study examined the following questions:

1. Does the current evaluation process successfully combine outcomes assessment to ensure quality learning occurs in collegiate aviation distance education courses?

2. Does the process of accrediting collegiate aviation programs reflect the needs of the new e-learning environment as seen by distance education providers?

Higher education is a dynamic entity reflecting the changing needs of society. Technological advances, in addition to shifting demographics, have a significant impact on the direction of higher education as it determines the role of e-learning in collegiate aviation (Eaton, 2001a). Efforts to assure quality in delivery and learning can be reflected in higher education's efforts to determine the needs and requirements of 
standard or nonstandard evaluation procedures.

\section{Participants}

This study rests on the foundation laid by two previous research projects. The first white paper explored the accreditation standards applied to distance education programs throughout various disciplines as well as national and regional accrediting bodies that compose the Commission of Secondary Schools (Bowen, et al, 2000). The second research component attempted to develop an accurate database of aviation education programs in the United States. Participants for this group came from educational institutions listed in the Collegiate Aviation Guide: Reference Guide of Collegiate Aviation Programs. The guide only lists colleges and universities that offer aviation courses or majors, but provides no information about distance education. Therefore, a survey was distributed via mail to each institution questioning its current and future involvement in collegiate aviation distance education (Bowen, et al., 2001). The Distance Education Aviation Program (DEAP) Survey established the increasing role of distance education in serving aviation students. The flexibility of distance education is especially appealing for aviation students already employed in the industry. Such programs are able to fit into their dynamic time and location schedules as well as reflect the requirements of an everchanging industry. Additionally, the need for program standards and assessment was seen as a key issue for the success of further distance programs (Bowen, et al, 2001).

Participants from the current study were selected primarily based on the DEAP responses for the 2000 study. Respondents who indicated participation in a distance education aviation program were also questioned about their program's evaluation criteria process. Since the database of aviation education programs does not currently include a distance education modifier, the snowballing technique was used to determine participants in the study. "Snowball refers to the process of accumulation as each located subject suggests other subjects" (Babbie, 1999, p.174). Snowballing was implemented to aid in the location of additional members of the target population who will provide information for locating other members of the same population.

\section{SURVEY}

Survey development.

A comprehensive development process (see Figure 1) was used to create the survey for this study. Research questions can be more accurately explored through a survey than a questionnaire (Wiggins \& Stevens, 1999). According to Wiggins and Stevens, survey questions can focus on broader issues and are not constrained by an individual premise. Since limited definite information is known about collegiate aviation distance education evaluation, the survey allows for a wider scope to acquire data. The content was generated from additional literature and an examination of prior surveys of similar study groups. The questionnaire underwent a multi-step analysis consisting of aviation content expert review and survey technique expert review. Individuals were termed experts based on their role in the industry and proven record through publications. The resulting feedback was incorporated into the questionnaire and then further examined by a test group based on an estimated $10 \%$ of the study group. The end result was the Program Evaluation for Aviation Distance Education Questionnaire (PEADEQ).

Survey design.

PEADEQ (see Appendix A) is 
primarily a structured phone interview guide that contains several unstructured questions at the end. The unstructured portion of the survey encouraged the snowballing effect and thus leads to additional suitable participants. The intent of the survey was to present an accurate cross-sectional design of the selected group of collegiate institutions offering distance education aviation programs. "Cross-sectional designs provide a portrait of a group during one time period" (Fink, 1995a, p.49). This account of the current state of the programs helps to gauge the development of evaluation measures, as well as the potential for use. All phone interviews took place within a one-week period at approximately mid-term to remove the likelihood of end-of-term or beginningof-term confusion and to assure that all programs were surveyed at approximately the same time in the academic year. While there is a slight incongruity for universities on the quarter system, the limitation is recognized without significant effect on the results of the study.

The author drafted the PEADEQ survey to quantitatively and qualitatively investigate the status of assessment within collegiate aviation distance education programs. The semi-structured interview guide took approximately five to ten minutes to complete. As this is self-reported data, it is expected that the participants provide to the " . . .best of his or her ability information on the areas of interest" (Hedrick, Bickman \& Rog, 1993, p. 70). An introductory statement is included to ensure all respondents have the same definition of distance learning (see Appendix A). "The introductory statement describes the survey and attempts to enlist participant cooperation" (Frey \& Oishi, 1999, p.43). An eligibility screen that determines the suitability of potential respondents follows this section. The actual questions round out the interview script.
The questionnaire consists of five parts, including an unstructured closure section where participants are asked exploratory questions to assist in the snowballing technique (Fink, 1995a). The questions are a combination of yes/no questions used in conjunction with items answered on a Likert-scale with ordinal measurement pattern options ranging from strongly agree to strongly disagree and a don't know option (Fink, 1995b). Several of the sections contain split-questions that aid in reducing the complexity of the question area (Frey \& Oishi, 1995). Therefore, respondents are not asked questions that are not relevant to their program.

All information that was to be read aloud to the respondents was in bold print to facilitate accuracy and consistency in the interviewing process (Frey \& Oishi, 1995). Interviewer instructions are in plain italicized text to help further distinguish them from questions. Based on the relatively small sample size, the author conducted all of the interviews. With only one interviewer, environmental and outside bias are held to a minimal level.

\section{Unit of Analysis}

The unit of analysis for this study is based at the institutional level. One representative from each applicable institution was interviewed. The individual, from each institution, was selected based on accessibility and ability to respond to questions based on a general knowledge of the distance education program. The positions of the individuals surveyed ranged from the departmental secretary to the director of the program. Since the survey is based on the use of assessment and evaluation techniques on the aviation distance education program overall, it would be inadvisable to consider the results on a course-by-course basis. 


\section{Validation}

The survey was revised based on the input of established experts in the fields of both aviation education and distance education. "A design is internally valid if it is free from nonrandom error or bias" (Fink, 1995a, p.56). Additionally, in an effort to reduce response error and increase clarity, a pretest was conducted using distance education programs without an aviation component. Based on $\mathrm{n}=26$, three universities were used in the pre-test validation process. According to Frey \& Oishi (1995), "Not only should pretesting be conducted on members of the relevant population, the instrument should also be pretested on interviewers and coders" (p.108). The survey design was modified based on responses from the pretest group as well as interviewer reaction. The changes improved the flow of the survey, resulting in increased clarity and ease of response.

\section{RESEARCH OUTCOMES}

Distance education has undergone a metamorphosis in response to the increased advancements in technological delivery. Many aspects of distance education, such as quality delivery and effective student learning, are complicated to define and measure. The accrediting institutions acceded that guidelines must be developed that attend to both traditional delivery and distance education. Evaluation was an essential aspect of these guidelines and should focus not just on course delivery and course content, but also on actual student learning and faculty feedback. Consideration of these factors will assist in the development of more effective evaluation guidelines that support high-quality distance education.

Based on the findings of the literature review, evidence illustrated the growing role distance education was beginning to play in education as a whole, and in particular collegiate aviation. CHEA spearheaded progressive research to examine the limitations and opportunities presented by elearning and outcomes-based evaluation procedures. While some educators continued to resist the advent of e-learning, the AFT was making every effort to protect the quality of all education through promoting faculty training to include online teaching as well (AFT, 2000). Likewise, the CAA took a proactive stance in making certain the distance programs that were part of its sphere of influence upheld quality standards. By examining the pitfalls encountered by other fields of study, professionals creating and delivering collegiate aviation distance education were attempting to circumvent these issues. Regular and timely evaluations procedures were a key element in prolonging the success of traditional learning as well as e-learning (Bowen, 1999).

The regional and national accrediting bodies and the collegiate aviation programs were at similar levels of development regarding distance education. The number of universities offering e-learning opportunities was growing every day (CHEA, 2001). However, they were still in the minority. The governing bodies recognized the change as real and imminent. As a result, numerous studies investigating the subtle and obvious similarities and differences offered insight and perspective to address the concerns of the students and the instructors alike (NCA, 1998).

The accreditation boards for various professions outside of aviation took a mixed view of distance education. While the difficulty of conducting a laboratory class online was obvious, there were other currently unrecognized uses for employing various aspects of e-learning into the engineering and hard science environment (ABET). Several of the professional boards 
failed to recognize the possible benefits of incorporating e-learning, but based on findings studying similar areas, this was likely to change.

\section{Survey Outcomes}

The survey results further corroborated these findings. From an original population of $n=26,24$ universities were surveyed. Two additional universities in the U.S. were identified as possible providers of aviation distance education courses (See Appendix B), but were not available when contacted for the survey. Finding administrators of distance education programs was limited by the flexible nature of the media. In contrast to traditional courses, instructors in e-learning were not bound to the office facility. A survey conducted via e-mail, as opposed to the telephone, may have been a more appropriate tool for this method of survey. When possible, follow-up contact was made via e-mail. The primary limitations to be considered for this study were that there were relatively few schools involved in delivering aviation-specific courses via distance education. While the nature of the content does not limit the applicability to distance learning, some schools found some Federal Aviation Administration (FAA) requirements restrictive. Additionally respondents may not have been completely objective in their analysis of their evaluation status for the program considered. These shortcomings were addressed and partially compensated for by the other areas of analysis.

At the time of this study, 14 U.S. universities verified that they engaged in aviation distance education. An additional 3 universities were believed to offer collegiate aviation distance education programs based on responses from snowballing and website crosscheck. Also, 10 other universities offering collegiate aviation programs were surveyed. These schools provided distance delivery, but there were no aviation offerings in this area. While distance delivery was indeed an option all universities were exploring, based on the survey responses, e-learning was not a method they took lightly in view of the difficulty other departments and programs have had with the delivery method.

Based on survey indicators, universities offering aviation courses via distance education played an active role in exploring the possible options of distance delivery and e-learning. Additionally, all programs quickly pointed out the complex nature of the evaluation issue when framing the elearning environment. According to the results from PEADEQ, the universities' planning process for developing distance education courses and programs showed a similar flow (see Figure 2). Typically the universities determined if there was a need for an e-learning program based on student and faculty interest and the curriculum requirements. If the need was established, the institution developed a program to meet the mutual needs and to fulfill the necessary outcomes. The program was implemented and usually reviewed as part of the regional accreditation process. Throughout the process, student and instructor evaluation occurred and outcomes were measured. The information from these evaluations was then fed back into the program. While the current program may have been of high quality, constant monitoring occurred to make sure it continued to be true.

There was no easy fit or simple standard that addressed the multiple needs of the e-learning student or instructor. Several of the universities were stepping back and conducting comprehensive studies of distance education before adding courses or proceeding with their programs. The advent of new technology made many of the advances in e-learning possible. 
Unfortunately, technology proved to be a major stumbling block both in the essence of conducting the course and then integrating it into the evaluation process.

Comments from the PEADEQ participants revealed chronic problems with establishing the necessary technical support and training to sustain distance education courses. The frustration at investing considerable time and effort into a program that could be outdated tomorrow by the introduction of new technology was particularly difficult to combat. Technology was a program's greatest ally and most formidable foe when difficulties appeared. While many of the respondents had plans in progress for creating aviation distance education courses, they were approaching the delivery method cautiously. The resources needed to launch such a program weighed heavily not only in funding, but also faculty time and cooperation. Considerable upfront time was cited as a major concern for introducing a quality program. Not all curriculums were found to be suitable for e-learning.

A broad range of aviation distance education programs exists in the U.S. Additional courses and exchanges occurred with international partners to increase the depth of learning and experience for aviation students. Undergraduate and graduate degrees, as well as certificates, could be earned all or partially via e-learning. See Appendix $\mathrm{C}$ for a complete listing of degrees. Increasingly, entirely online programs were offered that never require a student to come to campus (See Table 1). In some cases graduate degrees were available entirely online, while undergraduate degrees were not. Of the universities already offering aviation courses via distance, 10 of the 14 schools plan on expanding the distance education program, with only 1 school voicing strong disagreement with expansion.

\section{Table 1. Entire Program Can Be Completed via Distance Learning}

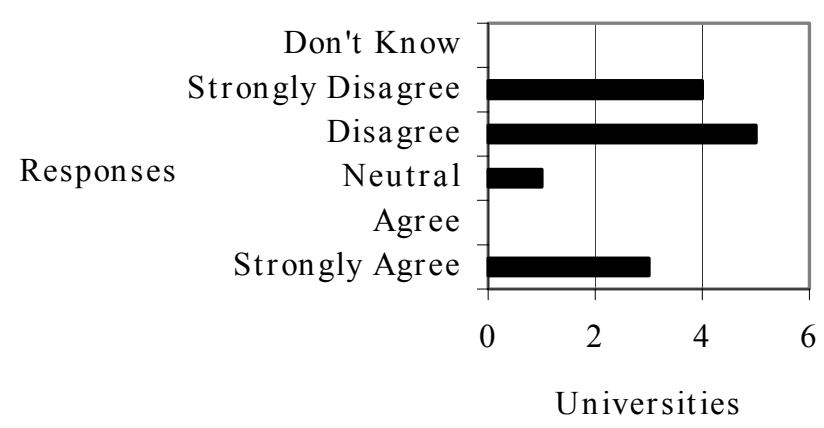

Universities offered varying amounts of distance courses that would count toward an aviation degree. This study included nonaviation courses, as well as actual aviation courses, that enabled a student to pursue some form of aviation degree from the associate through the bachelor and graduate level. Courses counting toward various certificates, such as private pilot or air operations management, were included. Of the six programs offering only 1-5 distinct courses throughout the year, plans were in progress to increase the depth of their distance opportunities in all but one case. Additionally, three universities offered 1120 distinct courses via distance delivery annually. The remaining schools fell singly into each of the course offering categories of $5-10,21-30,31-40$, and more than 50 distinct courses annually.

Evaluation is a key factor in maintaining the viability of not only the course, but also the entire e-learning program. Universities are experimenting with different types of evaluation procedures to ensure the quality of learning delivered meets expectations and industry standards. The majority of the programs use student evaluations as at least one aspect of the evaluation process. Aviation courses taught to meet FAA requirements have the 
additional evaluation advantage of the official FAA certification process to confirm effective learning occurred. The measuring of student outcomes met with mixed results depending in part on the type of course taught. Several schools used FAA testing to measure the success of student learning. This was typically done in conjunction with other measures such as tests of communication skills and regular quizzes to assess learning throughout the term. Four of the schools mentioned faculty response and evaluation to determine the student outcomes. In only one case were learning outcomes established for each course with every aspect of the delivery tied into standardized outcomes across distance learning. In section three of the survey, universities were queried as to whether the current evaluation process was effective for maintaining quality standards as well as if additional procedures were necessary to assess the quality of the distance program. Although the respondents replied favorably regarding their current evaluation process, many thought additional procedures were necessary for assessing the distance education experience. One respondent agreed somewhat to both questions and is not included in the responses for Figure 3 pictured below.

Figure 3. Quality Evaluation Procedures for Distance Program

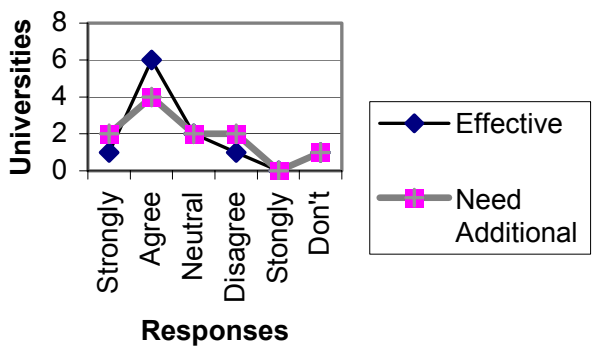

This study discovered that nearly half of the schools with aviation distance education used the same evaluation processes to assess distance delivery as the traditional method. The other universities expressed concern for using the same measures and recommended at least a variation in the mechanism to account for, at the very least, the technological component to distance delivery. Often questions on student surveys were geared toward elearning, but the questionnaire remained comparative. One university said, "The best distance education depends more on measurement of student outcomes...need multiple methods of student outcomes such as a portfolio and testing." This line of questioning found an overall lack of continuity between the schools in distance delivery. Most implied they were close to having the proper procedures in place, but they were not quite there.

The final aspect of the survey dealt with accreditation familiarity, including the role the Council on Aviation Accreditation (CAA) plays in the accrediting process. Both programs with aviation distance programs and without such programs were included in the testing population. All the questions in this section were based on the Likert scale, ranging from strongly agree, agree, neutral, disagree, strongly disagree, to don't know. All but a couple of respondents either strongly agreed or agreed to being familiar with regional accreditation programs as well as the role of CAA in the accreditation process. However, both groups were nearly split on knowledge of CAA's involvement in distance education accreditation. The responses divided further when they were asked about what standard should be applied to e-learning. Three questions (see Figure 4) covered this area and included options from using the same standards as for traditional classroom, separate standards for e-learning, or an open-ended outcomes-based assessment. The responses are broken down by universities with aviation distance education courses in series 1 and those with only 
aviation courses in series 2 .

Even though many of the respondents shied away from the traditional standards for distance education, they were not opposed to them entirely. The traditional methods could still be applied, just not fully or singly. Since a different medium was being used, standards needed to reflect that without lowering the amount of learning that needed to occur. The terms outcomesoriented and open-ended outcomes met with some skepticism, as they were so loosely defined. According to PEADEQ results, most acknowledged that, "Student learning was the key factor more so than how they were able to get there." Figuring out how to get there seems to be the problem.

\section{IMPLICATIONS FOR THE NEXT STAGE}

The findings result in the provision of recommendations to better the evaluation process of aviation distance education courses. Additional assessment will provide guidance in modifying the curriculum for enhanced achievement. While accreditation standards provide some guidance for developing and implementing distance education courses in relation to the traditional courses, the standards are not responsive to the changing needs, opportunities, and limitations of e-learning.

Programs that may be considered pioneers in aviation distance education, due to their relative longevity, recognize the constantly shifting framework surrounding distance education. They have an active role in the development of standards and principles. For all of their enthusiasm and experience, they remain concerned about actual specifications and potential limitations placed on distance education. See Appendix D for a full listing of comments from both sets of survey participants.

Evaluation procedures are either formally or informally in place to regularly assess the quality of aviation distance education programs throughout the nation. Assessment is a required part of an accredited program. Determining the viability and usability of the information provided by these processes is another matter entirely. Additional procedures need to be established that recognize the unique nature of distance delivery. This factor must be worked into the evaluation process in order to accurately and fairly assess the program and make the necessary changes. While student learning may be the same, the delivery makes a big difference in measuring the quality of the learning experience. 
Figure 1. Survey Design Process

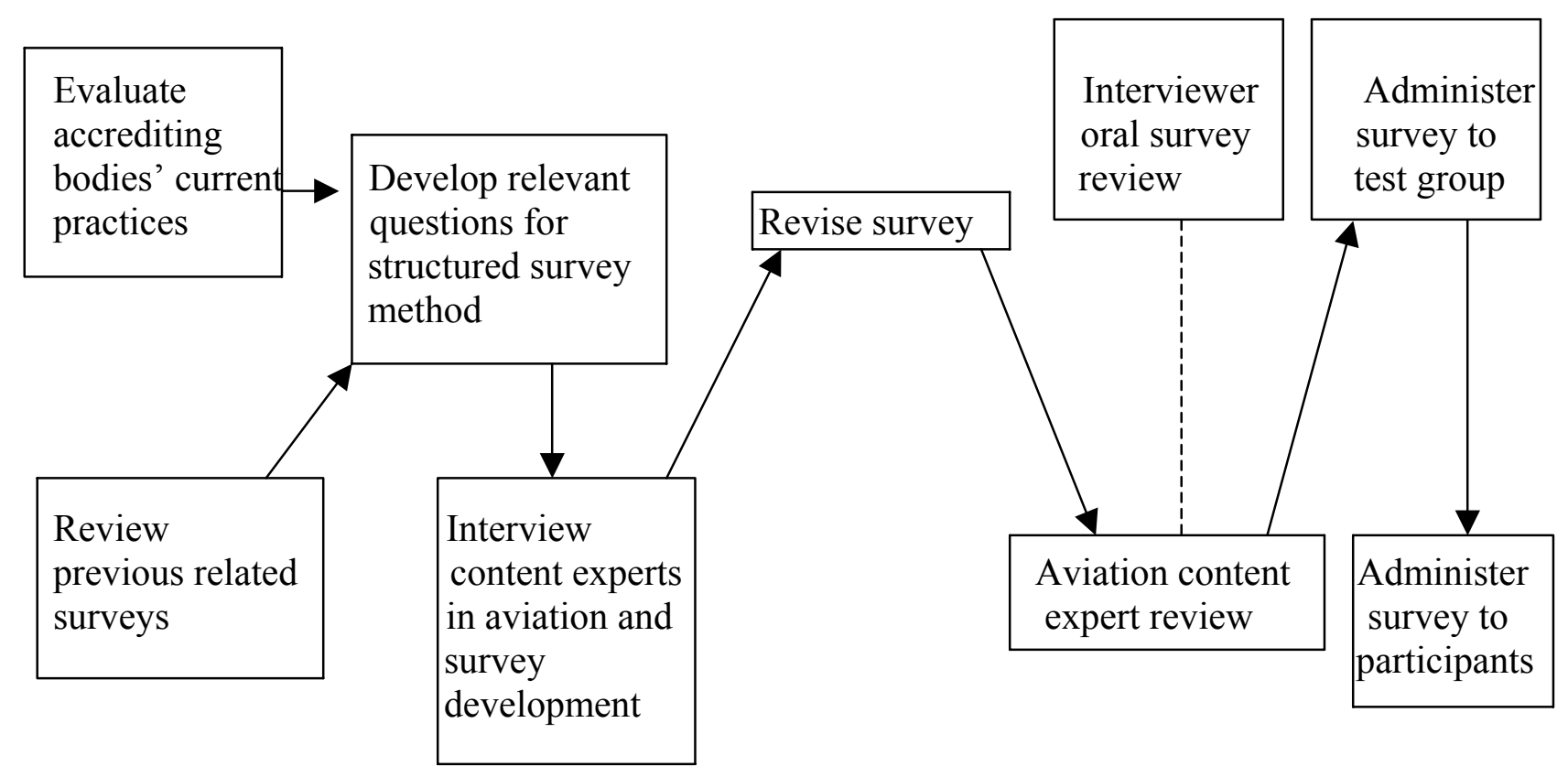


Figure 2. Program Development in Distance Education

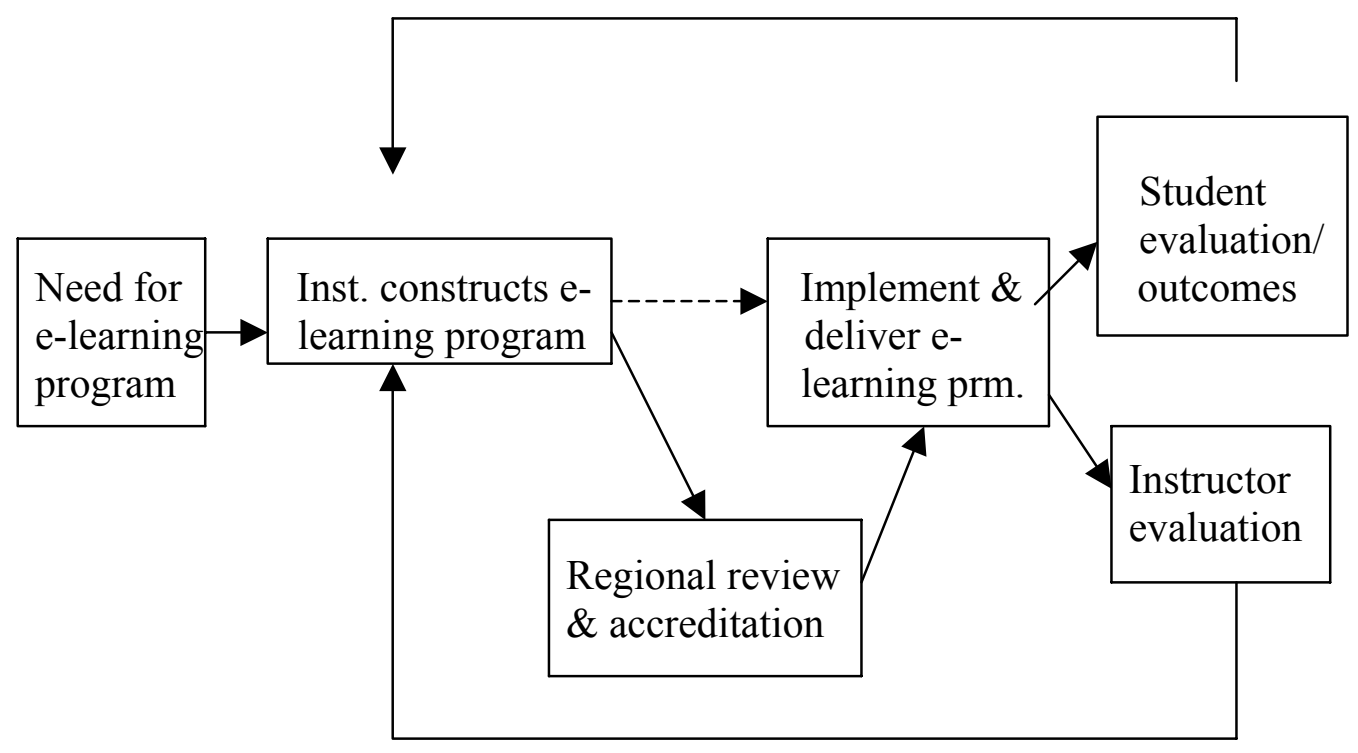


Figure 4. Standards Applied to E-learning in Terms of CAA Evaluation

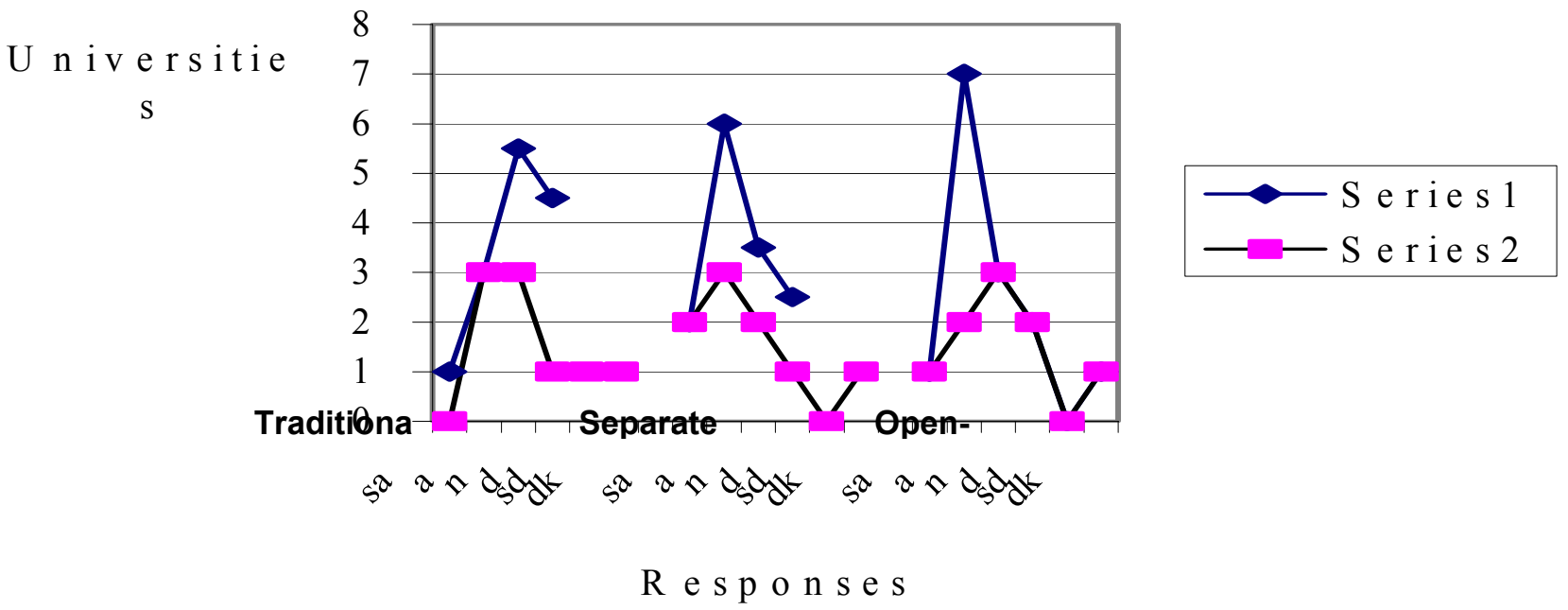




\section{REFERENCES}

Ad hoc Committee for Distance Education. (1998). A report to the Council on Aviation Accreditation Board of Directors. [Online]. Available:

http://cid.unomaha.edu/ unoai/caa/de21398.html

American Federation of Teachers. (2000, May). Distance education: Guidelines for good practice. Higher Education Program and Policy Council of the American Federation of Teachers. Online. Available at http://www.aft.org/higher_ed/reports/

Babbie, E. (1999). The basics of social research. Belmont, CA: Wadsworth Publishing Company.

Bowen, B. (1998). Content Analysis [Online]. Available:

http://cid/unomaha.edu/ unoai/avn8120/tools/definitions/contentanalysis.html

Bowen, B., Freeman, A., Scarpellini, N. \& Schaffart, M. (2000). White paper on accreditation issues for distance education in collegiate aviation. Unpublished manuscript. University of Nebraska at Omaha.

Bowen, B., Scarpellini, N., Fink, M. \& Freeman, A. (in press). "Accreditation of collegiate aviation's distance education programs: Now and in the future." Journal of Aviation/Aerospace Education and Research. Embry-Riddle Aeronautical University, Daytona Beach, FL.

Bowen, B., Scarpellini, N. \& Vlasek, S. (1999, October). Measuring student responses to improve instructional effectiveness in computer-mediated courses. Paper presented at the $2^{\text {nd }}$ Annual Partners in Education and Research Conference. Kennedy Space Center" Cape Canaveral, FL.

Burnham, B.R. (1994, August). "A systematic view of distance education evaluation: Finding our bearings." Presented at the $10^{\text {th }}$ Annual Conference on Distance Teaching and Learning. Madison, WI.

Carnevale, D. (2001, February 2). "Union offers standards for distance education." The Chronicle of Higher Education. [Online]. Available:

http://chronicle.com/free/v47/i21/21a03304.htm

Commission on Secondary Schools: Middle States Association of Colleges and Schools. (2001). What is accreditation. [Online]. Available: http://www.css-msa.org/accredit.html

Eaton, J.S. (2000). "FOCUS: assuring quality in distance learning." Council for Higher Education Accreditation reprinted from The Presidency Fall 2000: American Council on Education.

Eaton, J.S. (2001a). "Core academic values, quality, and regional accreditation: The challenge of distance learning." Council for Higher Education Accreditation Website. Online. Available: http://www.chea.org/Commentary/core-values.cfm

Eaton, J.S. (2001b). "The competency standards project: Another approach to accreditation review." Council for Higher Education Accreditation Website. Online. Available: http://www.chea.org/Commentary/core-values.cfm

Fink, A. (1995a). How to design surveys: The survey kit book 5. Thousand Oaks, CA: Sage.

Fink, A. (1995b). The survey handbook: The survey kit book 1. Thousand Oaks, CA: Sage.

Frey, J.H. \& Oishi, S.M. (1995) How to conduct interviews by telephone and in person. The survey kit book 4. Thousand Oaks, CA: Sage.

Green, K.C. (1999). "When wishes come true: Colleges and the convergence of access, lifelong learning, and technology." Change, 11-15. 
Hedrick, T.E., Bickman, L., Rog, D. J. (1995). Applied research design: A practical guide. Thousand Oaks, CA: Sage.

Krzycki, N. (1998). "Six aspects of distance learning and their impact on student satisfaction." Unpublished manuscript, University of Nebraska at Omaha. Online. Available:

http://www.unomaha.edu/ wwwpa/project/krzycki.html

Merisotis, J.P. \& Phipps, R.A. (1999, May/June). "What's the difference? Outcomes of distance vs. traditional classroom-based learning." Change (31) 3, 13-17.

Nachmias, D. \& Frankfort-Nachmias, C. (1996). Research methods in the social sciences $\left(5^{\text {th }}\right.$ ed.). New York: St. Martin's Press.

National Association of Schools of Public Affairs and Administration. (1998). NASPAA distance learning survey. Online. Available: http://cid.unomaha.edu/ wwwpa/nasdistntml

North Central Association of Schools and Institutions. (1998). An overview of accreditation: The criteria for accreditation. [Online]. Available:

http://www.ncacihe.org/overview/ovcriteria.cfm Review.

Oblinger, D. \& Kidwell, J. (2000 May/June). “Are We Being Realistic?” EDUCAUSE

O’Neal Jr., H.F., Bensimon, E.M, Diamond, M.A. \& Moore, M.R. (1999, November/December). "Designing and implementing an academic scorecard." $\underline{\text { Change (31) } 6 .}$ 33-40.

Scott-Fredericks, G.L. (1997). The graduate student experience in computer-mediated classes: A grounded theory study (Lotus Notes, distance education). Unpublished doctoral dissertation, University of Nebraska-Lincoln.

U.S. Department of Education. (1999). Higher Education Act of 1999, Fed. Reg. 64, 602.3, 20 U.S.C. 10996. [Online]. Available: http://www.access.gpo.gov/nara/index.html

University of Continuing Education Association. (1999). Regulatory fact sheet:

Promoting high-quality distance education: Distance education demonstration programs and learning anytime anywhere partnerships. [Online]. Available:

http://www.nucea.edu/DELAPP.htm

University of Massachusetts School of Education. (1974-1975). Clinic to improve

teaching $3^{\text {rd }}$ Annual Report. Amherst, MA: W.K. Kellogg Foundation.

Weigand, K. (2000, November). “Adult learners and distance education evaluation: Implications for success.” Barry University, Florida.

Western Association of Schools. (1998). Policy statement on distributive learning and technology-mediated instruction. [Online]. Available:

http://www.wascweb.org/senior/GUIDE/POLICY/HTM

Western Interstate Commission for Higher Education. (1999). Principles of Good

Practice for Electronically Offered Academic Degree and Certificate Programs. Western Cooperative for educational telecommunication. [Online]. Available:

http://www.wiche.edu/telecom/projects/balancing/principles.htm

Wolf. D. \& Johnstone, S. (1999, July/August). "Cleaning Up the Language:

Establishing a Consistent Vocabulary for Electronically Delivered Academic Programs" Change (31) 4. 34-39.

Acknowledgements:

The authors acknowledge guidance provided by the Council on Aviation Accreditation Ad Hoc Committee on Distance Education in the development of this research work. 


\section{APPENDIX A}

\section{Program Evaluation for Aviation Distance Education Questionnaire (PEADEQ)}

Institution:

Contact Name:

Phone:

Date:

For the purpose of this survey, please consider distance education to consist of distance learning and/or distributive learning that occurs through any form of e-learning or multiple method crossover delivery which includes any type of electronic delivery. This encompasses online teaching and learning, as well as academic support and student support services that are fully or partially electronically delivered.

This survey is being conducted by the University of Nebraska at Omaha Aviation Institute and supported by the Council on Aviation Accreditation Ad hoc Committee on Distance Education.

SCOPE OF PROGRAM

Does your institution offer any courses via distance delivery? (1)

$\mathrm{Y} / \mathrm{N}$

Answer NO

When does your institution plan to offer distance education courses? (1 na)

\begin{tabular}{|c|c|c|}
\hline Next term & Within 5 years & Never \\
\hline \multicolumn{3}{|c|}{ What methods might institution use? (i.e. technological add to existing courses) (1nb) } \\
\hline E-mail & Video Conference & Other \\
\hline
\end{tabular}
Go to ADDITIONAL SOURCES SECTION

Answer YES-Continue

Do you offer aviation courses via distance education? (2)

$\boldsymbol{Y} / \mathbf{N}$

Answer NO

$>$ Your institution plans to offer aviation courses via distance in the next year. (2na)

$\begin{array}{lllll}\text { Strongly Agree Agree Neutral Disagree } & \text { Strongly Disagree } & \text { Don't }\end{array}$

Know

$>$ Your institution plans to offer aviation courses via distance at some other time in the future. (2nb) 


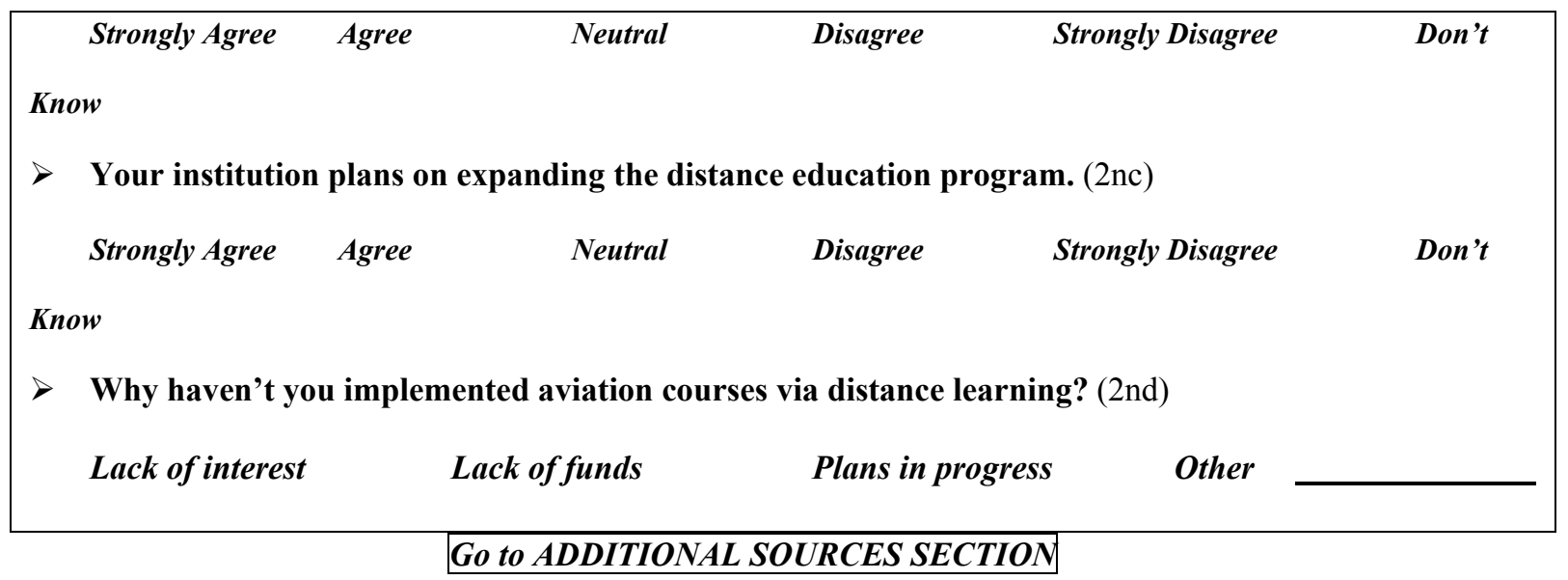

$>$ How many aviation courses do you offer via distance? (2ya)

$$
\begin{array}{lllll}
1-5 & 5-10 & 11-20 & 21-30 & 31-40
\end{array}
$$

$>\quad$ What kind of degrees or certificates can a student earn via distance coursework? (2yb)

Undergraduate Graduate Other

$\quad$ How is it (are they) titled?

$>\quad$ A student can complete the entire degree program via distance learning. (2yc)

$\begin{array}{lllll}\text { Strongly Agree Agree Neutral Disagree } & \text { Strongly Disagree }\end{array}$

Know

$>\quad$ The institution is planning on expanding the distance education program. (2yd)

$\begin{array}{lllll}\text { Strongly Agree Agree Neutral Disagree } & \text { Strongly Disagree }\end{array}$

Know

QUALITY MONITORING

Do you have an evaluation process in place? (3)

$\mathbf{Y} / \mathbf{N}$

Answer NO

$>$ Why not? (3na) 


$$
\text { Time constraints Budget constraints Faculty resistance Other }
$$

$>$ How do you assess the quality of your program? (3nb)
Questionnaire
Word of mouth
Student success rates
Other

$>$ The institution is planning on implementing an evaluation process. (3nc)

$$
\text { Strongly Agree Agree Neutral Disagree Strongly Disagree Don't }
$$

Know

$>$ The process used to assess distance programs differs from the process used to assess traditional programs.
(3nd) Strongly Agree
Agree
Neutral
Disagree
Strongly Disagree

\section{Don't Know}

How is it different and/or similar? (3ne)

Answer YES

$>$ What does the process consist of? (3ya)

$>$ How often do you evaluate the programs? (3yb)

$$
\text { Every term Twice a year Annually Other }
$$

$>\quad$ What additional procedures, if any, are used to evaluate the distance programs? (3yc)

How do you measure outcomes? (3yd)

Student evaluations Student response/success Faculty response Other

$>\quad$ The current evaluation process is effective for maintaining quality standards. (3ye)

$$
\text { Strongly Agree Agree } \quad \text { Neutral DisagreeStrongly }
$$

Disagree

Don't Know

Additional procedures are necessary to assess the quality of the distance program. (3yf) 


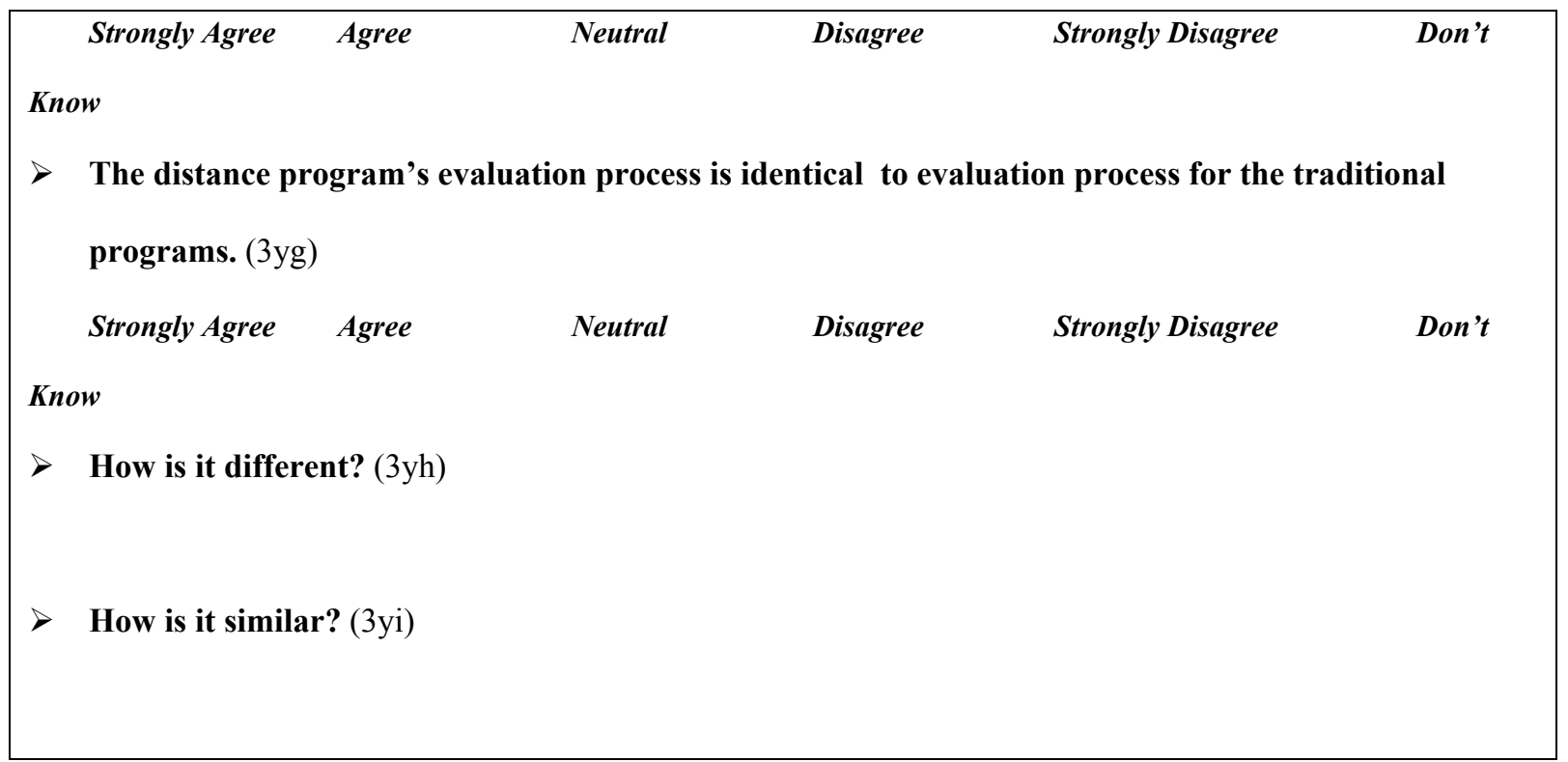

\section{ADDITIONAL SOURCES SECTION}

Do you know of any other universities that offer aviation courses via distance education? (4) $\underline{\mathrm{Y} / \mathrm{N}}$

\section{Answer NO-Go to CLOSURE SECTION}

Which universities does this include? (4ya)

\section{ACCREDITATION FAMILIARITY}

$>$ I am familiar with regional accreditation programs. (a4a)

$\begin{array}{lllll}\text { Strongly Agree Agree } & \text { Neutral Disagree } & \text { Strongly Disagree }\end{array}$

Know

$>$ I am familiar with the role the Council on Aviation Accreditation plays in the accreditation process. $(\mathrm{a} 4 \mathrm{~b})$

$\begin{array}{lllll}\text { Strongly Agree } & \text { Agree } & \text { Neutral Disagree } & \text { Strongly Disagree } & \text { Don't }\end{array}$

Know 
$>$ I am aware that the Council is engaged in distance education accreditation (a4c)

$\begin{array}{lllll}\text { Strongly Agree } & \text { Agree } & \text { Neutral } & \text { Disagree }\end{array}$

Know

Existing standards for traditional classrooms should be applied to e-learning. (a4d)

$\begin{array}{lllll}\text { Strongly Agree } & \text { Agree } & \text { Neutral Disagree } & \text { Strongly Disagree }\end{array}$

Know

$>$ The Council should have separate standards for E-learning. (a4e)

$\begin{array}{lllll}\text { Strongly Agree Agree Nentral Disagree } & \text { Strongly Disagree }\end{array}$

Know

$>$ Rather than specific standards, an open-ended outcomes based assessment should be used for CAA

evaluation. (a4f)

$\begin{array}{lllll}\text { Strongly Agree Agree } & \text { Neutral Disagree } & \text { Strongly Disagree }\end{array}$

Know

$>$ Which accreditation standard does your program follow (check all that apply)? (a4g)

Regional Collegiate Aviation Association Other

\section{CLOSURE SECTION}

Is there anything you would like to add that I may have missed? (5)

$>$ What would you like to know about this study? (6). 


\section{Appendix B}

\section{Universities Offering Aviation Courses via Distance Delivery}

Arizona State University; Mesa, CA

California State University-Los Angeles; Los Angeles, CA

College of Aeronautics; Flushing, NY

Delta State University; Cleveland, MS

Eastern Michigan University; Ypsilanti, MI

Embry-Riddle Aeronautical University-Ext. Campus

Indiana State University, Terre Haute, IN

Louisiana Tech University; Ruston, LA

Mercer County Community College; Trenton, NJ

Metro State College of Denver; Denver, CO

Naugatuck Valley Community Technical College; Woodbury, CT

Northwestern Michigan College; Raverse City, MI

Thomas Edison State College*; Trenton, NJ

University of Nebraska-Kearney; Kearney, NE

University of Nebraska-Omaha; Omaha, NE

University of North Dakota*; Grand Forks, ND

University of Utah*; Salt Lake City, UT

*Did not respond to survey 


\section{Appendix C}

\section{Degrees/Certificate Titles Earned Via Distance Education per PEADEQ}

Associate Degrees

Aircraft Turbine Engine

Aviation Business

Aviation Customer Relations

Aviation Science Aviation Technology

Applied Sciences in Customer Relations

Applied Sciences \& Flight Technology

Applied Sciences \& Technology

Arts in Aviation Management

General Flight

Bachelor of Arts

Aviation Business Degree

Business Management \& Aviation

General Studies in Aviation Studies

Bachelor of Science

Aviation Management

Aviation Technology

Management of Technical Operations

Professional Aeronautical Science

Professional Aeronautics

Professional Aviation

Master Degrees

Aeronautical Science

Business Administration

Commercial Aviation

Liberal Studies with Aviation Concentration

Public Administration with Aviation Concentration

Urban Studies with Aviation Concentration

Doctoral Degrees

Education Administration with Aviation Focus

Public Administration with Aviation Concentration

Certificates

Air Operations Management

Private Pilot Ground

Instrument, Pilot Ground

Commercial Pilot Ground

Certified Flight Instructor Ground 


\section{Appendix D}

\section{Is there anything you would like to add I may have missed?}

Schools with no aviation distance education

- Graduate programs are a source for distance education, but no approval needed; in traditional degree have an accreditation standard and a body to look at quality of program; establish a program for distance education graduate study.

- Haven't figured out how to handle requirements of FAR Part 141; think we will reexamine when university works through bugs of distance education already in place.

- Not off hand.

- No separate standards yet. Traditionally based, but think through what's happening with different delivery methods it will. Difficult to determine quality. Distance quality issues include determining quality via e-learning is a tough quality to measure. Quality of e vs. traditional in terms of certain subject matter and ability to deliver it. Certain subjects lend themselves well, some don't. Like mixed mode option where there's the best compromise to meet people's schedules. Believe in it as much as possible. We want to take advantage of the opportunity of distance delivery without giving up quality. Depends so much on people. Time involved at front end of course is tremendous. Accreditation should address the front end of course to get at what's behind the course.

\section{Schools with aviation distance education courses}

- Believe that accreditation should occur, but unsure as to the manner. A lot of courses aren't worth the e-mail--little more than directed reading. A stand-alone course without visuals is useless in this industry. Planning on creating a CD and DVD to accompany courses.

- Currently working to set-up an international program with Lufthansa. JAR standards and language create interesting problems/issues.

- Appreciative of professional bodies that are looking at how distance learning is shaping up. Confident that it will steer us in the right direction. I'd be happy to be involved in helping.

- Accountability; evaluate program on national level and provide publicity for professional status.

- In process of setting standards.

- Look into PictureTel Video Conferencing and moving to online.

- Surveys are slanted and misleading.

- Distance learning is the way of the future. Technology is improving rapidly. When trying to assess D.L. you're assessing the past, not a good indicator about the future. Video stream is a good method.

- Distance education is moving so quickly and changing so rapidly. A couple of people are on top of it at my university with the most advanced library. All we've learned is how much is unknown. I'd be very careful because who's going to do the accreditation? It's a stumbling block when people without technical backgrounds come in and evaluate what they don't know. It's important to take a step back and watch. Asynchronous versus synchronous can make a big difference. 